\title{
IRAK1 Gene Mutation
}

National Cancer Institute

\section{Source}

National Cancer Institute. IRAK1 Gene Mutation. NCI Thesaurus. Code C157586.

A change in the nucleotide sequence of the IRAK1 gene. 